\title{
Analisis Timbulan Dan Karakteristik Sampah Kegiatan Akademik Di Universitas Nahdlatul Ulama Nusa Tenggara Barat
}

\author{
Baiq Siti Mutajaridah ${ }^{1}$, Uzlifatul Azmiyati ${ }^{2}, G_{\text {Gendewa Tunas Rancak }}{ }^{3}$ \\ Program Studi Teknik lingkungan, Fakultas Teknik Universitas Nahdlatul Ulama NTB \\ Jl. Pendidikan No.6, Dasan Agung Baru, Kecamatan Selaparang, Kota Mataram, \\ Bqsiti334@gmail.com
}

\begin{abstract}
Abstrak.Saat ini volume sampah yang tinggi di Kota Mataram merupakan salah satu permasalahan yang sangat serius. Berdasarkan data yang diperoleh, sampah yang tidak terangkut di Kota Mataram berjumlah 37\%. Permasalahan sampah juga terjadi di Universitas Nahdlatul Ulama NTB yang merupakan Universitas swasta dengan 4 Fakultas dan 10 Program studi. Sampai saat ini Universitas Nahdlatul Ulama NTB tidak melakukan pengelolaan sampah dan masih membuang sampah ke TPA.Tanpa adanya pengelolaan sampah yang baik, volume sampah di Universitas Nahdlatul Ulama NTB cenderung bertambah seiring meningkatnya aktivitas dan jumlah penghuni kampus.Hal ini tentu akan mengakibatkan meningkatnya tumpukan sampah di wilayah kampus yang dapat menimbulkan berbagai dampak kesehatan lingkungan seluruh penghuni kampus. Penelitian ini bertujuan untuk menganalisis timbulan dan karakteristik sampah kegiatan akademik di Universitas Nahdlatul Ulama NTB.Sebagai salah satu dasar dalam pengelolaan sampah yang berkelanjutan di Universitas Nahdlatul Ulama NTB.Hasil penelitian menunjukkan bahwa Universitas Nahdlatul Ulama NTBmasih menggunakan sistem angkut lalu dibuang.Rata-rata volume sampah yang dihasilkan kampus per hari adalah2.746, $25 \mathrm{~m}^{3} /$ hari.
\end{abstract}

Kata kunci: Timbulan Sampah, Karakteristik Sampah, Universitas Nahdlatul Ulama NTB

Abstract.At present the high volume of waste in the city of Mataram is one of the very serious problems. Based on the data obtained, the garbage that is not transported in Mataram City is 37\%. Waste problems also occur at the University of Nahdlatul Ulama NTB which is a private university with 4 faculties and 10 study programs. Until now the University of Nahdlatul Ulama NTB has not carried out waste management and is still throwing garbage into the landfill. Without good waste management, the volume of garbage at the NTB Nahdlatul Ulama University tends to increase with the increase in activity and the number of campus residents. in the campus area which can cause various environmental health impacts for all campus residents. This study aims to analyze the generation and characteristics of waste academic activities at the University of Nahdlatul Ulama, West Nusa Tenggara. As one of the bases in sustainable waste management at the University of Nahdlatul Ulama, West Nusa Tenggara. The amount of campus garbage produced per day is 2,746, 25m3 / day.

Keywords: Waste Generation, Waste Characteristic, Universitas Nahdlatul Ulama NTB

\section{PENDAHULUAN}

Sampah telah menjadi masalah yang sangat besar dibeberapa tempat termasuk di Kota mataram. Kota Mataram memiliki luas wilayah sebesar $61,30 \mathrm{~km}^{2}$, dan pada tahun 2012 jumlah penduduk mencapai 413.210 jiwa. Tingkat kepadatan penduduk mencapai 6.741 jiwa $/ \mathrm{km}^{2}$, dengan ini persentase pertumbuhan penduduk sebesar 1,51 persen. Kota Mataram yang merupakan ibu kota Provinsi NTB dalam perkembangan prekonomian melaju sangat pesat kondisi ini juga diikuti jumlah sampah yang meningkat dengan munculnya berbagai pembangunan, perhotelan, dibukanya tempattempat pariwisata, perumahan-perumahan dan pasar-pasar modern. 
Jurnal Ilmu Sosial dan Pendidikan

http://ejournal.mandalanursa.org/index.php/JISIP/index

Terakreditasi Peringkat 5 (No. SK: 85/M/KPT/2020)

Permasalahan sampah di Kota Mataram tidak hanya pada volumenya saja.Tetapi disebabkan kurangnya kinerja (kesanggupan) antar instansi-instansi dalam pengangkutan sampah mulai dari rute dan penjadwalan pengangkutan sampah yang tidak efisien.Dari perkembangan penduduk dan perkembangan perekonomian ini berdampak pada peningkatan volume sampah diberbagai Tempat Pembuangan Sementara (TPS). Menurut data BPU Provinsi NTB untuk wilayah Kota Mataram timbulan sampah mencapai 1250.00 $\mathrm{m}^{3} /$ hari namun yang terangkut hanya 786.00 $\mathrm{m}^{3} /$ hari atau hanya sekitar $63 \%$. Berdasarkan data tersebut maka ada sekitar $464 \mathrm{~m}^{3} /$ hari atau $37 \%$ yang tidak terangkut (Khalika 2015)

Sampah merupakan salah satu permasalahan yang sangat kompleks dan sangat luas saat ini. Tidak hanya terjadi di daerah pemukiman atau di kota Mataram melainkan dapat terjadi di kawasan yang mempunyai penghuni yang sangat padat, salah satunya seperti kawasan kampus termasuk di Universitas Nahdlatul Ulama NTB merupakan salah satu perguruan tinggi swasta yang didirikan sejak tahun 2014, yang berlokasi di Jln. Pendidikan No.6, Dasan Agung Baru, Kecamatan. Seleparang, Kota Mataram, Nusa Tenggara Barat. Universitas Nahdlatul Ulama NTB mempunyai 4 fakultas dengan 10 program Studi. Universitas Nahdalatu Ulama NTB mempunyai jumlah mahasiswa sebanyak 1.117 mahasiswa dari angakatan 2015-2019.jumlah dosen 83 orang dan ditambah dengan jumlah para pegawai yang berjumlah lebih dari 10 orang seluruhcivitas Universitas Nahdlatul Ulama NTB.ditambah jumlah pascasarjana UIN mataram (akademik), Ma Alma'arif (setaf TU), pegawai kantin, dan petugas kebersihan menghasilakan sampah setiap harinya.

Tingginya jumlah penghuni kampus berpengaruh terhadap volume sampah yang dihasilkan oleh kampus yang memiliki berbagai macam aktivitas seperti belajar, mengajar, dan aktivitas lainnya.Sampah yang di hasilkan sebagian besar merupakan sampah anorganik seperti botol plastik, kardus, dan kertas Hvs,
Vol. 4. No. 3 Juli 2020

p-ISSN: 2598-9944 e-ISSN : 2656-753

dan sebagian kecil berupasampah organik,seperti sayur-sayur busuk, buah-buahan busuk, ikan, dan lain sebagainya. Adapun sampah residu merupakan sampah seperti, bungkus snack, bungkus nasik, putung rokok, tisu basah, penumpukan serta pembuangan sampah secara sembarangan tidak memecahkan masalah, tapi justru menambah masalah bagi lingkungan kampus, Seperti menimbulkan bau, dan bisa menimbulkan berbagai penyakit tentunya di lingkungan kampus.Kondisi ini dapat memberikan dampak yang tidak baik pada kesehatan lingkungan dan estetika kawasan kampus.

Tujuan dari penelitian ini adalah untuk menganalisis jumlah timbulan, volume dan karakteristik sampah yang ada di Universitas Nahdlatul Ulama NTB.Hal ini penting untuk dilakukan sebagai dasar dalam pengelolaan sampah yang berkelanjutan di Universitas Nahdlatul Ulama NTB.Peneliti berharap hasil dari penelitian ini dapat digunakan untuk membuat sistem pengelolaan sampah hingga menjadi solusi dalam masalah persampahan di wilayah kampus Universitas Nahdlatul Ulama NTB.

\section{TINJAUAN PUSTAKA}

\section{Timbulan Sampah}

Sampah merupakan bahan atau barang yang sudah tidak digunakan dari hasil kegiatan sehari-sehari manusia dan alam. Disebabkan sampah yang berasal dari perhotelan, pasar, industri dan istansi-istansi yang menyebabkan pencemaran terhadap lingkungan sebagai sumber penyakit terhadap kesehatan.(Hasibuan 2016). Sampah merupakan barang yang dianggap sudah tidak terpakaidan dibuang oleh pemilik/pemakai sebelumnya,tetapibagi sebagianorangmasih bisa dipakai jikadikelola dengan proseduryangbenar.(Panji Nugroho, 2013).

Dalam merencanakan suatu sistem pengelolaan persampahan diperlukan suatu pola standar atau spesifikasi sebagai suatu landasan yang jelas. Spesifikasi yang digunakan adalah Standar Nasional Indonesia (SNI) Nomor T-121991-03 tentang Tata Cara Pengelolaan 
Terakreditasi Peringkat 5 (No. SK: 85/M/KPT/2020)

Sampah di Permukiman, Standar Nasional Indonesia (SNI) Nomor T-13-1990 tentang Tata Cara Pengelolaan Teknik Sampah Perkotaan, Standar Nasional Indonesia (SNI) Nomor S-041993-03 tentang Spesifikasi Timbulan sampah untuk Kota Kecil dan Sedang di Indonesia.

Adapun rumus untuk menghitung timbulan sampah menurut SNI dilihat di bawah ini:

$$
\text { jumlah sampah }=\frac{\text { jumlah sampah }}{\text { jumlahharisampling }}
$$

Dimana :

\begin{tabular}{|c|c|}
\hline Timbulan & jumlah sampah per hari dalam $\mathrm{kghari}$ atau $\mathrm{m}^{3} / \mathrm{hari}$. \\
\hline Jumlah sampah & $\begin{array}{l}\text { jumlah sampah (dalam } \mathrm{kg} \text { atau } \mathrm{m}^{3} \text { ) yang dihitung saat } \\
\text { melakukan } \\
\text { sampling }\end{array}$ \\
\hline Jumlah hari sampling & $\begin{array}{l}\text { jumlah hari dilakukan pengukuran dalam } 1 \text { bulan ( } 6 \text { hari } \\
\text { kantor, } 8 \text { hari untuk wisma werdhapura. }\end{array}$ \\
\hline
\end{tabular}

\section{Volume Sampah}

Volume sampah adalah masa berat jenis yang diperoleh dari perbandingan berat sampel dengan volume ukuran kotak kompaksi yang digunakan untuk sampah dengan menggunkan perhitungan sampah dari Trilina (2010). Untuk menghitung volume sampah dengan cara memindahkan sampah dari trash beg kedalam kompaktor dan mengukur tinggi sebelum dan sesudah dilakukan kompaksi. Pengkompaksi dilakukan dengan cara menghentakan kompaktor sebanyak 3 kali ketanah dengan cara mengakat kompaktor setinggi $20 \mathrm{~cm}$. volume sampah yang digunakan untuk menghitung bsaran volume adalah setelah dilakukan kompaksi. pengukuran berat sampah dengan menimbang sampah dari masingmasing sampel. Dengan rumus dibawah ini :

Rumus timbulan /hari

$$
\text { berat sampah }(\mathrm{kg})
$$

$\overline{\text { Jumlah unit penghasil samaph }\left(\mathrm{m}^{2} / \mathrm{orng} / \mathrm{hari}\right.}$

\section{Karakteristik Sampah}

Karakteristik sampah di suatu wilayah sangat penting untuk diketahui.Hal ini berguna untuk mendapatkan volume serta potensi sampah yang bisa didaur ulang kembali dan untuk mengudentifikasinya permasalahan pada pengelolaan sampah.Karakteristik sampah ditinjau dari beberapa aspek yaitu karakteristi fisik, karakterisik kimia, dan karakteristi biologis.Karakteristik fisik ini penting dalam hal pemilihan dan pengoperasian peralatan dan fasilitas pengolahan. Parameter karakteristik fisik antara lain:

a. Berat Jenis

Berat jenis adalah berat bahan per satuan volume $\left(\mathrm{kg} / \mathrm{m}^{3}\right)$. Berat jenis akan sangat bergantung pada lokasi geografi, musim, tahunan, dan lama waktu penyimpanan, ini digunakan tipe-tipe khusus. Karena berat jenis sangat penting untuk diketahui dalam desain pengelolaan sampah yang akan digunakan pada desain pengakutan, penyimpanan, dan pembuangan (gaur, 2008)

b. Kelembaban

Kelembaban di bagi menjadi dua cara yaitu dengan metode berat basah dan berat kering pada umumnya nilai berat sampah bergantung pada kondisi iklim di wilayah tersebut. (gaur, 2008)

c. Faktor pemadatan

Konduktifitas hidrlok sampah yang dipadatkan merupakan sipat fisik yang penting dalam skala besar.

d. Kapasitas lahan

Kapasitas lahan merupakan total jumlah kelembaban yang dapat menahan berat sesuatu diatasnya akibat grafik.

\section{METODE PENELITIAN}

Dalam pelaksanaan penelitian inidigunkan metode kuantitaif dan deskriptif kualitatif. Teknik pengumpulan data antara lain survey lapangan, dan wawancara kemudian melakukan analisis data. Wawancara dilakukan terhadap sampel acak yang telah dipilih untuk mewakili penghuni kampus tanpa secara keselurhanya masing-masing dari sampel sumber sampah.Sampel yang diambil dalam penelitian ini adalah sampah Organik dan Anorganik.Sampel ini dipilih karena jensi sampah inilah yang paling banyak dihasilkan di Universitas Nahdlatul Ulama NTB.Sampel sampah ini diambil dengan menggunakan metode yang tercantum dalam SNI 19-39641994 yaitu dengan pengumpulan dan 
pengukuran sampel sampah selama 8 hari berturut-turut.

\section{HASIL DAN PEMBAHASAN}

\section{Timbulan Sampah}

Dari hasil pengukuran yang dilakukan selama 8 hari berturut-turut, diperoleh hasil yang berbeda setiap harinya. Adapun hasil perhitungan timbulan sampah Universitas Nahdlatul Ulama NTB dapat dilihat pada Tabel 1 dibawah ini:

Tabel 1. Timbulan Sampah

Universitas Nahdlatul Ulama NTB $\mathrm{kg} /$ orang/hari

\begin{tabular}{|l|c|c|c|c|c|c|c|c|c|}
\hline \multirow{2}{*}{$\begin{array}{l}\text { Sampel } \\
\text { sampah }\end{array}$} & \multicolumn{8}{|c|}{ Berat timbulan sampah hari ke 1-8 (kg) } & $\begin{array}{c}\text { Total hari } \\
(\mathrm{kg})\end{array}$ \\
\cline { 2 - 11 } & 1 & 2 & 3 & 4 & 5 & 6 & 7 & 8 & \\
\hline Organik & 10 & 8 & $\begin{array}{r}10, \\
5\end{array}$ & 8 & 13 & 6,5 & 3 & 3 & 81,5 \\
\hline Aorganik & 13,5 & 11,5 & 9,5 & $\begin{array}{r}14, \\
5\end{array}$ & $\begin{array}{r}10, \\
5\end{array}$ & 8 & $\begin{array}{r}14, \\
5\end{array}$ & 6.5 & 88,5 \\
\hline Residu & 11,5 & 10 & 8 & 9,5 & $\begin{array}{r}12, \\
5\end{array}$ & 7,5 & 15 & 7,5 & 62 \\
\hline
\end{tabular}

Berdasarkan hasil analisis yang telah dilakukan, diperoleh jumlah timbulan sebesar232 kg/orang/hari.Hal ini menunjukkan bahwa jumlah sampah yang dihasilkan melebih dari ambang sewajarnya atau batas maksimum. Maka dari itu, sampah tersebut tidak bisa diamankan begitu saja tanpa ada proses tindakan yang lebih khusus untuk menangani sampah yang ada di wilayah Universitas Nahdlatul Ulama NTB. Terlihat pada tabel 1 di atas bahwa tiga kelompok sampah yaitu organik, anorganik, dan residu memiliki jumlah yang berbeda beda. Sampah anorganik memiliki jumlah yang paling tinggi yaitu 88,5 $\mathrm{kg}$ /orang/hari dan sampah residu memiliki jumlah terendah yaitu $62 \mathrm{~kg} /$ orang/hari. Sedangkan jumlah sampah organik mencapai $81,5 \mathrm{~kg} /$ orang/hari.

\section{Volume sampah}

Volume sampah adalah massa berat jenis sampah yang diperoleh dari perbandingan berat sampel dengan volume $\left(\mathrm{m}^{3}\right)$. Berdasarkan hasil perhitungan dari perbandingan berat sampel dengan volume kotak $90 \mathrm{~cm}^{3}$, menggunakan perhitungan volume sampah dari Trilina (2010).Volume sampah yang dihasilkan di Universitas Nahdlatul Ulama NTB adalah sebanyak $2.746,25 \mathrm{~m}^{3} /$ hari.

\section{Komposisi Sampah}

Komposisi sampah merupakan gambaran dari masing-masing komponen yang terdapat pada sampah dan distribusinya.Pengelompokan sampah yang paling sering dilakukan adalah berdasarkan komposisinya dan dinyatakan dalam persen berat. Komposisi sampah dipengaruhi oleh faktor-faktor seperti frekuensi pengumpulan, musim, kondisi ekonomi, cuaca dan kemasan produk (Tchobanoglous, dalam Damanhuri \& Padmi, 2016)

Berdasarkan hasil analisis data yang telah dilakukan, diperoleh komposisi sampah yang ada diwilayah Universitas Nahdltul Ulama NTB. Komposisi sampah paling besar adalah sampah aorganik yaitu 45,28\%. Sampah organik menempati urutan kedua sebesar $30,19 \%$. Sampah organik di Universitas Nahdlatul Ulama NTB didominasi oleh sampah sisa makanan.Sedangkan sampah residu sebesar 24, 53\%. Komposisi sampah di Universitas Nahdlatul Ulama NTB digambarkan dengan lebih jelas seperti pada Gambar 1 berikut ini:

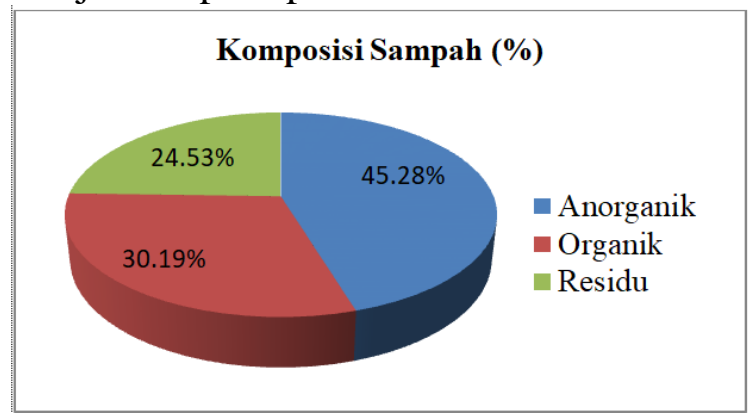

Gambar 1. Komposisi Sampah Dalam \% Berat di Universitas Nahdlatul Ulama NTB

\section{Karakteristik Sampah}

Berdasarkan analisis data yang telah dilakukan berikut adalah rata-rata karakteristik sampahyang dihasilkan, seperti yang tercantum pada Tabel 2 di bawah ini: berat jenis sampah merupakan berat material per unit sampah. 
Terakreditasi Peringkat 5 (No. SK: 85/M/KPT/2020)

Tabel 2.Karakteristik Sampah Universitas Nahdlatul Ulama NTB

\begin{tabular}{|c|c|c|c|c|}
\hline No & Bagian Sampah & Jenis-Jenis Sampah & $\frac{\text { Berat }}{(\mathrm{kg})}$ & $\begin{array}{c}\text { Komposisi } \\
(\%)\end{array}$ \\
\hline \multirow[t]{4}{*}{1} & Sampah Organik Basah & Sisa makanan & 3 & $11,32 \%$ \\
\hline & & Kulit buah & 1,5 & $5,66 \%$ \\
\hline & Sampah Organik Kerik & dedaunan kering & 2 & $7,55 \%$ \\
\hline & jumlah & & 6,5 & $24,53 \%$ \\
\hline \multirow[t]{8}{*}{2} & Sampah anorganik & Kardus & 2 & $7,55 \%$ \\
\hline & & Kertasa Hvs & 1,5 & $5,66 \%$ \\
\hline & & Gelasan & 3 & $11,32 \%$ \\
\hline & & Sedotan & 1 & $3,77 \%$ \\
\hline & & Pet bening & 1 & $3,77 \%$ \\
\hline & & Pet warna & 1,5 & $5,66 \%$ \\
\hline & & Pet campuran & 2 & $7,55 \%$ \\
\hline & Jumlah & & 12 & $45,28 \%$ \\
\hline \multirow[t]{6}{*}{3} & Sampah Residu & Bungkus snack & 1,5 & $5,66 \%$ \\
\hline & & Bungkus rokok & 1 & $3,77 \%$ \\
\hline & & Putung rokok & 2 & $7,55 \%$ \\
\hline & & Bungkus nasi & 1 & $3,77 \%$ \\
\hline & & Tisu basah & 2,5 & $9,43 \%$ \\
\hline & jumlah & & 8 & $30,19 \%$ \\
\hline 4 & jumlah total keseluruhan & & 26,5 & $100,00 \%$ \\
\hline
\end{tabular}

Sumber: Analisis Data 2019

Dari tabel di atas berdasarkan karakteristik sampah yang dihasilkan selama penelitian 8 hari berturut-turut peneliti melihat sampah atau jenis sampah yang paling dominan di wilayah Universitas Nahdlatul Ulama NTB, adalah jenis sampah Anorganik yaitu sebesar $45,28 \%$ sedangkan jenis sampah yang kurang atau sedikit yang dihasilkan yaitu jenis sampah Organik 24,53\%.

\section{KESIMPULAN}

Berdasarkan pada tujuan dilakukan penelitian ini, maka dari hasi penelitian dan pembahasan dapat diambil beberapa kesimpuln sebagai berikut :

1. Seluruh penghuni wilayah Uiniversitas Nahdlatul Ulama NTB belum memiliki pengelolaan sampah sendiri. Sistem pengelolaan sampah yang terdapt di wilayah kampus pada umumnya sama, masih sistem kumpul, angkut, dan buang begitu seterusnya baik dari pihak Universitas Nahdltul Ulama NTB, Al' ma'arif dan Pacasarjana UIN mataram, tidak ada yang mengelola sampahnya secara khusus.

2. Universitas Nahdlatul Ulama NTB menghasilkan timbulan sampah sebesar $232 \mathrm{~kg} /$ orang/hari atau 2.746, 25m ${ }^{3}$ dan menghasilkan komposisi sampah yang terdiri dari 30,19\%) Orgnik, \% Anorganik, dan 45,28\%), dan 24,53\% Residu
3. Timbulan sampah di pengaruhi juga oleh tingkat seluruh penghuni wilayah di Universitas Nahdlatul Ulama NTB.

4. Beberapa jenis sampah yang terdapat di wilayah Universitas Nahdlatul Ulama NTB yaitu sampah Organik, Anorganik dan Residu. perbandingan sampah dari tiga bagian yang terdapat di Universitas Nahdlatul Ulama NTB yaitu Organik 81.5 $\%, 88,5 \%$ Anorganik, dan Residu $62 \%$.

5. Adapun untuk volume sampah organic yang dihasilkan oleh Universitas Nhadlatul Ulama NTB yaitu $2.746,25 . \mathrm{m}^{3} /$ hari.

6. Potensi reduksi sampah oleh Universitas Nahdlatul Ulama NTB adalah sebesar $30.19 \%$ sampah organik untuk pengomposan dan $45.28 \%$ sampah anorganik untuk didaur ulang kembali dan $24.53 \%$ residu untuk dimanfaatkan kembali dan sisanya untuk dibuang ke TPA dari hasil pemilahan tentunya.

\section{UCAPAN TERIMA KASIH}

Penulis mengucapkan terima kasih kepada Allah SWT,Ibu Uzlifatul Azmiyati, S.Si., M.Sc, dan Bapak Gendewa Tunas Rancak. ST., M.T. Rekan-rekan Fakultas Teknik dan Prodi Teknik Lingkungan yang telah memberikan bantuan tenaga, semangat maupun pengetahuan dalam penelitian ini.

\section{DAFTAR PUSTAKA}

AndariG.S.b., Evynovita., dan ika putrid.(2011)

kebersihankota.blogspot.com/ unduh tanggal 1 juli 2014 januari.

Christiawan dan Citra, 2016.StudiTimbulan Dan KomposisiSampahPerkotaan di KelurahanBanyuning "Jurnal Media KomunikasiGeografi. vol 17. No. 2

Damanhuri P.T. 2018. Kajian Pencemaran Air Tanah Oleh Lindi Di SekitarTempatPembuanganAkhirSamp ah Air Dingin Kota

Padang.JurnalSains dan Teknologi Vol. 18 No.1.

Damanhuri,E., dan Padmi.,T.2010 Diktat Kuliah Pengelolaan Sampah TL3104.ITB,Bandung 
Terakreditasi Peringkat 5 (No. SK: 85/M/KPT/2020)

Fitri A.M, Dhaniswara T.K. 2017. Pengaruh Perlakuan Awal Sampah Organik Terhadapproduksi Biogas Secara Anaerobic Digestion.Joumnal of Research and Technology, Vol.3. No.2

Gusniani D. 2013., DesainOperasiPenangananSampahKam pusUniversitas Indonesia Depok." Teknik Lingkungan, Fakultas Teknik, Universitas Indonesia, KampusBaru UI, Depok, 16424, Indonesia.

Hasibuan R. 2016. Analisis Dampak Sampah Terhadap Pencemaran Lingkungan Rumah Tangga. Jurnalllmiah “ Advokasi Vol.04.No.01,42-52.

Laylani W, 2016. Studitimbulan, komposisi dan

karakteristikSampahdomestikkotabukitt inggi.Teknik Lingkungan UNAND 9 (1) :Volume1-12 (Januari 2012) ISSN 1829-6084

Masud,

M., 2014 http://www.antarantb.com/print /23461/,"gerakan-lisan-upayamataram-atasi-persoalan-sampah," masnun-masudtanggal 13 Juni

Mahyudi P.R. 2017. Kajian Permasalah Pengelolaan Sampah Dan Dampak Lingkungan Di Tpa. JukungJurnal Teknik Lingkungan VOl.3. NO 1

Nugroho Panji, 2013.Panduan MembuatKomposCair.Jakarta: PustakabaruPress

Pandelaki E.E . 2011.Kajian PengelolaanSampahKampusJurusanAr sitekturFakultas Teknik UniversitasDiponegoro.JurusanArsitek turFakultas. MODUL Vol.11 No.2

Peraturan Pemerintah Republik Indonesia Nomor 81Tahun 2012 TentangPengelolaan

Sampah rumah tangga dan sampah sejenis sampah rumah tangga.

SNI SNI19-3964-1994TentangPengmbilan Dan Pengukuran Contoh Timbulan Dan Komposisi sampah
SNI 19-2454-2002 tentang Tata Cara Teknik Operasional Pengelolaan Sampah Perkotaan. (2002). Badan Standardisasi Nasional

SNI 13-1990-f Tentang Tata Cara Pengelolaan Sampah Perkotaaan.

Undang-undang R.I NOMER 18 Tahun 2008 Tentang Pengelolaan Sampah 